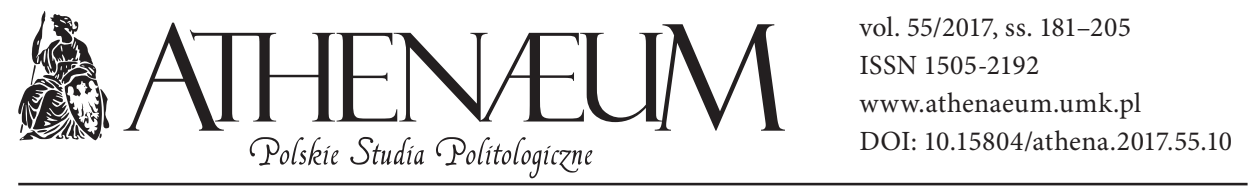

\title{
PRZYMIERZE W KRYZYSIE - POLITYKA WIELKIEJ BRYTANII WOBEC TURCJI PO ATAKU NIEMIECKIM NA ZWIAZZEK SOWIECKI
}

\author{
THE ALLIANCE IN CRISIS: THE POLICY OF GREAT BRITAIN \\ TOWARDS TURKEY AFTER THE GERMAN ATTACK \\ ON THE SOVIET UNION
}

Krzysztof Zdulski*

\begin{abstract}
- ABSTRAKT
18 czerwca 1941 roku Turcja podpisała z III Rzeszą układ o nieagresji. Wydarzenie to spotkało się z krytycznym przyjęciem ze strony Wielkiej Brytanii. W Londynie pojawiły się obawy o zmianę polityki tureckiej, której kurs do tej pory nastawiony był na bliską współpracę $\mathrm{z}$ aliantami.

Cztery dni później III Rzesza zaatakowała Związek Radziecki. Reakcja rządu brytyjskiego była błyskawiczna. Winston Churchill podjął decyzję o udzieleniu pomocy napadniętemu, puszczając w niepamięć prawie dwa lata ścisłej współpracy niemiecko-radzieckiej. Ten krok z kolei wywołał niepokój w Ankarze, która uważała, że polityka jej północnego sąsiada zagraża suwerenności i integralności terytorialnej Turcji. Obawiano się, że rodząca się współpraca brytyjsko-radziecka może odbyć się kosztem państwa tureckiego.

Z końcem czerwca 1941 r. brytyjska polityka zagraniczna stanęła zatem przed dwoma ważnymi wyzwaniami. Dążąc do utrzymania przyjaznych relacji z Turcją, Brytyjczycy z jednej
\end{abstract}

On June 18th, 1941, Turkey signed a nonaggression pact with the Third Reich. This event was critically received by Great Britain. Fears were awoken in London of changes in the Turkish politics which had so far been oriented at close cooperation with the Allies.

Four days later the Third Reich attacked the Soviet Union. The British government reacted immediately. Winston Churchill decided to offer aid to the attacked party, forgetting instantly about nearly two years of close German-Soviet cooperation. This move left Ankara anxious due to the conviction that the policy of its Northern neighbor threatened the sovereignty and territorial integrity of Turkey. It was feared that the uprising alliance might occur at the expense of Turkey.

At the end of June 1941, the British foreign policy faced two critical challenges. Aiming at maintaining amicable relations with Turkey, the British had to, on one hand, prevent Germany

* Uniwersytet Łódzki, Wydział Studiów Międzynarodowych i Politologicznych. 
strony musieli przeciwdziałać zbliżeniu niemiecko-tureckiemu, a $\mathrm{z}$ drugiej przekonać władze tureckie, że brytyjska współpraca ze Związkiem Sowieckim nie będzie stanowić zagrożenia dla interesów tureckich. Powyższe cele wyznaczyły główne kierunki działań dyplomacji brytyjskiej wobec Turcji na następne półtora roku.

W pierwszym przypadku odniesiono połowiczny sukces. Co prawda Turcja nie została objęta niemiecką strefą wpływów, ale dyplomatom brytyjskim nie udało się storpedować turecko-niemieckiej umowy gospodarczej, a zwłaszcza jej najważniejszego punktu, czyli przywrócenia eksportu chromu do III Rzeszy. Brytyjczycy jedynie opóźnili dostawy dzięki wyegzekwowaniu od rządu tureckiego przestrzegania zawartego na początku 1940 roku porozumienia, którego postanowienia obowiązywały do końca 1942 roku.

W drugim przypadku Brytyjczycy uczynili wszystko co było w ich mocy, aby rozwiać obawy tureckie. Najpierw w sierpniu 1941 roku przekonali władze Związku Sowieckiego do wydania oświadczenia, w którym deklarowano przestrzeganie integralności terytorialnej Turcji. Następnie wiosną 1942 roku, kiedy negocjowany był układ brytyjsko-radziecki, Moskwa i Londyn potwierdziły wcześniejsze zobowiązania. Należy jednak zauważyć, że dyplomacja brytyjska nie ustrzegła się przed popełnieniem kilku błędów, które mogły zwiększyć podejrzenia ze strony rządu tureckiego. Najpoważniejszym z nich było niepoinformowanie Turków o przygotowaniach do brytyjsko-radzieckiej interwencji w Iranie, do której doszło pod koniec sierpnia 1941 roku.

Słowa kluczowe: Wielka Brytania, Turcja, Związek Sowiecki, Trzecia Rzesza, chromit, druga wojna światowa and Turkey from entering close cooperation, and on the other, convince the Turkish authorities that the British cooperation with the Soviet Union would not pose a threat to the Turkish interest. The above aims determined the main direction of policy of the British diplomacy towards Turkey over the next year and a half.

In the first case the success was achieved partially. Turkey was not included in the German scope of influence but the British diplomats failed to undermine the Turkish-German economic contract, especially its most important point, i.e., reinstating the export of chrome to the Third Reich. The British only managed to delay the delivery by having the Turkish government observe the agreement concluded at the beginning of 1940, whose provisions were valid until the end of 1942.

In the second case the British did whatever they could to put the Turkish concerns at ease. First, in August 1941, they convinced the Soviet Union authorities to issue a statement in which they declared that they would respect Turkey's territorial integrity. Next, in the spring of 1942, when the British-Soviet alliance was subject to negotiation, Moscow and London confirmed their previous commitments. It must be, however, observed that the British diplomacy did not manage to avoid a few mistakes that may have strengthened the suspicions of the Turkish government. The most important one was not having informed the Turkish of the preparations for the British-Soviet intervention in Iran which was led in late August 1941.

Keywords: Great Britain, Turkey, Soviet Union, Third Reich, chrome, the Second World War

18 czerwca 1941 r. Turcja podpisała z III Rzeszą układ o nieagresji. Cztery dni później Wehrmacht rozpoczął operację „Barbarossa”, czyli kampanię przeciwko Związkowi Sowieckiemu. Oczywiście pierwsze wydarzenie nie miało wpływu na podjęcie decyzji o drugim, gdyż ta zapadła kilka miesięcy wcześniej, a dokładniej 
rzecz biorąc w grudniu 1940 r. (Dębski, 2007, s. 465-466). Nie oznacza to, że obie daty nie korespondowały ze sobą. Nie bez znaczenia był bowiem fakt, że niemalże w przeddzień niemieckiej ofensywy rząd turecki zabezpieczył newralgiczną, bałkańską flankę państw Osi.

Powstała sytuacja wywołał konsternację w obozie aliantów, a zwłaszcza w Wielkiej Brytanii. Od podpisania brytyjsko-francusko-tureckiego układu o wzajemnej pomocy 19 października 1939 r. Turcja była uważana za państwo sprzyjające aliantom. Pomimo że w czerwcu 1940 r. Ankara nie wywiązała się ze swoich zobowiązań sojuszniczych, a następnie odrzuciła możliwość przystąpienia do wojny po włoskim ataku na Grecję, to pozostawała w strefie wpływów politycznych Wielkiej Brytanii (Zdulski, 2015). Fakt ten miał doniosłe znaczenie dla rządu brytyjskiego, gdyż już w okresie „dziwnej wojny” państwo tureckie zostało uznane za pierwszą linię obrony interesów brytyjskich na Bliskim Wschodzie przed agresją z północy (Zdulski, 2016). Jak łatwo domyślić się, w ciągu następnych kilkunastu miesięcy przekonanie to uległo pogłębieniu, do czego walnie przyczyniło się objęcie kontrolą Europy Południowo-Wschodniej przez państwa Osi. W tym kontekście niemiecko-turecki układ o nieagresji mógł się jawić jako pierwszy krok do podporządkowania Turcji III Rzeszy, na co Wielka Brytania nie mogła sobie pozwolić.

Atak niemiecki na Związek Sowiecki również nie pozostał bez wpływu na politykę brytyjską wobec Turcji. Winston Churchill, podejmując decyzję o udzieleniu pomocy Józefowi Stalinowi, puszczając tym samym w niepamięć blisko dwa lata ścisłej współpracy przywódcy Związku Sowieckiego z Adolfem Hitlerem, dał dużo do myślenia stronie tureckiej. W Turcji polityka jej północnego sąsiada uważana była, przynajmniej od czasów wizyty ministra spraw zagranicznych Şükrü Saracoğlu w Moskwie z przełomu września i października 1939 r., za zagrożenie dla integralności terytorialnej państwa tureckiego. Pojawiło się zatem pytanie, czy rodząca się współpraca brytyjsko-sowiecka nie rozwinie się kosztem Turcji. Kwestia ta nie mogła zostać zignorowana przez dyplomację brytyjską, o ile decydenci znad Tamizy nadal chcieli utrzymać Turcję w swojej strefie wpływów politycznych.

Z nastaniem końca czerwca 1941 r. przed polityką brytyjską wobec Turcji pojawiły się dwa wyzwania: storpedowanie dalszego zbliżenia turecko-niemieckiego oraz zdyskontowanie współpracy brytyjsko-sowieckiej, a przynajmniej jej zneutralizowanie. Czy Brytyjczycy odnieśli sukces w obu albo przynajmniej jednym przypadku? Odpowiedzi na to pytanie została poświęcona niniejsza praca. W oparciu o materiały archiwalne przechowywane w National Archives 
w Londynie analizie poddane zostały decyzje rządu Wielkiej Brytanii, czyli tzw. gabinetu wojennego, oraz działalność dyplomacji brytyjskiej. Przy wykorzystaniu bezpośredniej metody ustalania faktów historycznych ocenione zostało półtora roku polityki brytyjskiej wobec Turcji, od wybuchu wojny sowiecko-niemieckiej do przełomu w europejskim teatrze wojny, który wyznaczyły bitwa pod Stalingradem oraz pod Al-Alamejn w Afryce Północnej. Należy jednak zastrzec, że niniejsza praca nie pretenduje do całościowego ujęcia polityki brytyjskiej we wspomnianym okresie. Wiele wątków zostało jedynie zasygnalizowanych, jak np. wpływ przystąpienia Stanów Zjednoczonych do wojny na politykę brytyjską wobec Turcji. Zagłębienie się w poboczne kierunki polityki brytyjskiej wobec Turcji doprowadziłoby do rozmycia w gąszczu informacji wspomnianych dwóch najważniejszych zadań dyplomacji brytyjskiej, a zatem negatywnie odbiłoby się na przejrzystości wywodu.

Podejmowana w niniejszej pracy problematyka nie doczekała się opracowania w polskiej literaturze przedmiotu. Jest ona oczywiście obecna w dorobku światowym, aczkolwiek jest najsłabiej rozpoznanym wątkiem zarówno brytyjskiej polityki zagranicznej wobec Turcji podczas II wojny światowej, jak i stosunków brytyjsko-tureckich w tym okresie. Praktycznie więcej uwagi poświęciło jej dwóch autorów: John Robertson (1986) oraz Nicholas Tamkin (2009). Pierwszy z nich przeprowadza zdecydowanie bardziej wnikliwą i analizę o szerszym spectrum, ale opartą na niekompletnym materiale archiwalnym - wiele dokumentów odtajnionych zostało w latach dziewięćdziesiątych oraz na początku XXI wieku. Mankament ten nie dotyczy pracy Tamkina. Jednak główny nacisk położony w niej został na relacje w trójkącie Wielka Brytania-Turcja-Związek Sowiecki, co spowodowało, że problem zbliżenia niemiecko-tureckiego dla polityki brytyjskiej jest jedynie ledwo dostrzegalny.

Zawarcie 18 czerwca 1941 r. niemiecko-tureckiego układu o przyjaźni i nieagresji spotkało się z krytycznym przyjęciem ze strony Londynu. Tego samego dnia Alexander Cadogan zapisał w swoim dzienniku: „Turcy definitywnie podpisują dzisiaj - niech będą przeklęci - przekazaliśmy instrukcje dla prasy, najlepsze, jakie można było. Oczywiście FO będzie winione za ten stan rzeczy" (The Diaries of Sir Alexander Cadogan, 1938-1945, 1971, s. 389). Mniej niechętni stronie tureckiej niż stały podsekretarz stanu w Urzędzie Spraw Zagranicznych (Foreign Office, dalej: FO) politycy i urzędnicy brytyjscy również nie kryli swojego rozczarowania. Podczas przemowy w Izbie Parów szef FO Anthony Eden pogardliwie odnosił się do tego wydarzenia, a w trakcie debaty były sekretarz stanu ds. wojny Leslie Hore-Belisha stwierdził, że Niemcy będą mogły przez 
Turcję uderzyć w interesy brytyjskie na Bliskim Wschodzie. Sytuację starał się uspokoić jedynie premier Wielkiej Brytanii Winston Churchill, zapewniając posłów, że jeśli Turcja miałaby wybrać między Wielką Brytanią a Niemcami, to wybierze pierwszą opcję (Robertson, 1986, s. 56-57). Niektórzy uważali, że należy ukarać Ankarę. Sir Robert Vansittart, główny doradca dyplomatyczny rządu, proponował wstrzymać dostawy niszczycieli budowanych dla państwa tureckiego w Wielkiej Brytanii (Foreign Office, dalej: FO, 371/30040/R 6759). Podobnie sądzono w Urzędzie ds. Wojny (War Office, dalej: WO). Dwa dni po zawarciu niemiecko-tureckiego układu Komitet Szefów Sztabów (Chiefs of Staff - dalej COS) złożył na ręce Komitetu Koordynacji Dostaw Sojuszniczych (Committee for the Co-ordination of Allied Supplies, dalej: CCAS) wniosek o ograniczenie wysyłki do państwa tureckiego sprzętu wojskowego, surowców naturalnych oraz produktów przemysłowych. Jako uzasadnienie podawano potrzebę wzmocnienia obrony Wysp Brytyjskich, niedobory w Iraku i na Bliskim Wschodzie oraz zwrot w polityce Turcji (Cabinet Papers, dalej: CAB, 66/17/11, k. 76).

Propozycje takie były bardzo niebezpieczne i ryzykowne. Ambasador brytyjski w Turcji sir Knatchbull-Hugessen, ostrzegał przed popychaniem Ankary w ramiona Niemiec. Podkreślał, że Turcy byli przerażeni demonstracją potęgi Luftwaffe podczas kampanii bałkańskiej, co w jego opinii zadecydowało o podjęciu negocjacji, które doprowadziły do podpisania układu o nieagresji z III Rzeszą (FO 371/30126/R 6363, k 175.). Na marginesie warto dodać, że po latach w swoim pamiętniku Knatchbull-Hugessen stwierdził, że układ z Niemcami miał pomóc Turcji w przetrwaniu najcięższego okresu i nie oznaczał żadnej fundamentalnej zmiany polityki tureckiej (Knatchbulla-Hugessen, 1949, s. 171). Zarówno Eden, jak i pracownicy Departamentu Południowego FO całkowicie zgodzili się z wnioskami wyciągniętymi przez Knatchbull-Hugessena. W odpowiedzi na prośbę CCAS o wskazówki w temacie dostaw do Turcji szef FO przygotował memorandum, w którym zdecydowanie odradzał ograniczenie zaopatrzenia dla tego państwa. Zdaniem Edena odcięcie Turcji od dostaw brytyjskich byłoby równoznaczne ze złamaniem zobowiązań, które Wielka Brytania wzięła na siebie, podpisując układ o wzajemnej pomocy w październiku 1939 r. Na dodatek nastąpiłoby to w momencie, kiedy Londyn został zapewniony przez Turków, że funkcjonowanie tego traktatu zostało zabezpieczone poprzez odniesienie się do niego w preambule układu niemiecko-tureckiego. Jednak przede wszystkim szef FO zwracał uwagę na to, że jeżeli ograniczy się dostawy sprzętu wojskowego dla armii tureckiej, to Ankara uzna, że nad Tamizą przestano ufać stronie tureckiej albo że sytuacja militarna Imperium Brytyjskiego stała się zbyt ciężka, aby mogło 
ono pomagać swojemu sojusznikowi. To z kolei groziło całkowitym odcięciem się władz tureckich od aliantów i dalszemu zacieśnianiu relacji z III Rzeszą (CAB 66/17/14, k. 83). Opinia Edena znalazła poparcie wśród członków Komitetu Obrony (Demence Committee, dalej: DC), co ułatwiło przegłosowanie na zebraniu gabinetu wojennego utrzymaniu dostaw do Turcji na niezmienionym poziomie (CAB 65/18/42, s. 106).

Linia polityczna zaproponowana przez Edena była najbardziej rozsądnym i w zasadzie jedynym sposobem przeciwdziałania zbliżeniu niemiecko-tureckiemu. W tym czasie Wielka Brytania nie posiadała żadnych atutów. W konfrontacji z Wehrmachtem armia brytyjska ponosiła klęski, których nie mogły przysłonić pozorne, drugorzędne sukcesy, jak zdławienie powstania w Iraku czy powolne postępy interwencji w Syrii i Libanie. W grę nie wchodziło również zwiększenie dostaw sprzętu wojskowego dla państwa tureckiego, gdyż po wiosennych porażkach priorytetem było odbudowanie sił brytyjskich na Bliskim Wschodzie. Politycznie Wielka Brytania też nie miała wiele do zaoferowania. Od klęski Francji praktycznie sama prowadziła wojnę przeciwko III Rzeszy. Jednak niemiecki atak na Związek Sowiecki z 22 czerwca 1941 r. zmienił ten stan rzeczy. Tym samym pojawiło się pewne pole manewru.

Początkowo przyjęto w Turcji rozpoczęcie operacji „Barbarossa” z nieukrywaną ulgą, gdyż w tej sytuacji niebezpieczeństwo niemieckiej agresji na państwo tureckie spadało praktycznie do zera. Po krótkim czasie zdano sobie jednak sprawę z zagrożeń, które niosła nowa sytuacja. Najgorszym scenariuszem było zwycięstwo któregoś z mocarstw, co doprowadziłoby do jego dominacji na kontynencie europejskim. Negatywnie zapatrywano się również na perspektywę współpracy brytyjsko-sowieckiej, ponieważ mogła ona rozwinąć się kosztem interesów tureckich. Dla przeczulonych na tym punkcie Turków już przemówienie radiowe Churchilla wygłoszone w dniu niemieckiego ataku na Związek Sowiecki zapowiadało taki obrót spraw. Brytyjski premier, nawiązując do roli Rosji w I wojnie światowej, stwierdził, że została ona wówczas pozbawiona owoców zwycięstwa (The Churchill War Papers, 2001, s. 835-837). Zaniepokojony tymi słowami minister spraw zagranicznych Turcji Şükrü Saraçoğlu wezwał Knatchbulla-Hugessena i stwierdził, że uwaga Churchilla o niezaspokojeniu rosyjskich dążeń podczas poprzedniej wojny implikuje, że zostaną one spełnione po tej. Następnie dodał, że skoro Wielka Brytania nie zgodziła się na aneksję państw bałtyckich, to jedyne nabytki terytorialne, jakie będzie można zaoferować, znajdują się w Turcji. Przy okazji przypomniał, że podczas I wojny światowej Brytyjczycy obiecali Rosji cieśniny czarnomorskie (FO 371/30092/R 6581, k.3). 
FO z jednej strony starało załagodzić całą sytuację i zbagatelizować wymowę słów Churchilla (FO 371/30092/R 6581, k.5), a z drugiej postanowiło wykorzystać obawy tureckie do zdobycia punktu w rozgrywce dyplomatycznej z III Rzeszą o Turcję. Knatchbull-Hugessen został poinstruowany, aby przedstawić władzom tureckim następującą propozycję: poprzez wymianę not Wielka Brytania miała zobowiązać się do przestrzegania integralności terytorialnej Turcji, potwierdzić, że układ o wzajemnej pomocy z października 1939 r. jest trzonem polityki brytyjskiej wobec tego państwa oraz zapewnić, że nie zawrze z żadnym państwem toczącym $z$ Niemcami wojnę porozumienia, które wymierzone byłoby w życiowe interesy tureckie. W zamian Ankara miała zadeklarować, że układ z października 1939 r. nadal stanowi fundament tureckiej polityki zagranicznej, i zobowiązać się do niepodejmowania żadnych działań, które uderzałyby w interesy Wielkiej Brytanii (FO 371/30091/R 6352, k. 204). Ambasador brytyjski przekazał notę, ale sam był sceptycznie nastawiony do tego pomysłu. Jego zdaniem strona turecka przyjmie brytyjską deklarację z zadowoleniem, ale sama nie będzie chciała wydać oświadczenia o treści zaproponowanej przez Londyn. Może nawet potraktować takie żądanie jako działanie podjęte jej kosztem, co mogłoby jedynie zwiększyć podejrzenia Ankary. Skoro bowiem strona brytyjska uzależni wydanie deklaracji od takiego samego kroku przedsięwziętego przez drugą stronę, to będzie znaczyło, że w przypadku odrzucenia propozycji Londyn nie będzie czuł się zobowiązany do przestrzegania zasad w niej zawartych (FO 371/30092/R 6658, k. 19). Faktycznie Turcy nie przejawiali zbytniego entuzjazmu względem propozycji brytyjskiej, a całkowicie stracili zainteresowanie nią po podpisaniu układu brytyjsko-sowieckiego z 12 lipca 1941 r. Ze względu na fakt, że nie zostali poinformowani o tym wydarzeniu, poczuli się urażeni i zrobili bardziej podejrzliwi względem współpracy brytyjsko-sowieckiej (FO 371/30068/R 7097, k. 63).

W FO zdecydowano się zmienić taktykę. Zmniejszono presję na Ankarę, a w zamian postanowiono namówić Moskwę, aby w tym samym czasie co Londyn wydała jednostronne oświadczenie. Strona sowiecka miała w nim potwierdzić przestrzeganie postanowień konwencji z Montreux oraz podobnie jak Wielka Brytania zobowiązać się do respektowania integralności terytorialnej Turcji (FO 424/286, s. 32). Co prawda ambasador brytyjski w Związku Sowieckim uważał, że łatwiej będzie uzyskać zgodę, jeżeli Ankara również podejmie odpowiednie zobowiązania względem swojego północnego sąsiada, lecz sugestie te okazały się zupełnie niepotrzebne (FO 371/30068/R 7312, k. 83). Na początku sierpnia Iwan Majski, ambasador sowiecki w Londynie, zgodził się na propozycję Edena, 
a nawet zasugerował uzupełnienie jej o obietnicę udzielenia przez Związek Sowiecki pomocy Turcji w razie agresji na to państwo (CAB 65/19/15, s. 200). Zapewnienia brytyjskie i sowieckie zostały przekazane władzom tureckim 10 sierpnia i zostały zaakceptowane, przy czym poproszono o ich publikację (FO 371/30068/R 7582, k. 163). Eden nie krył zadowolenia. Podczas zebrania gabinetu wojennego podkreślił, że Ankara przyjęła dobrze oświadczenie brytyjskie i sowieckie (CAB 65/19/18, s. 211). Nie było to do końca zgodne z prawdą, albowiem obawy tureckie nie zostały rozwiane, do czego niebawem w dużym stopniu przyczyniła się brytyjsko-sowiecka interwencja w Iranie.

Wkroczenie Armii Czerwonej i wojsk brytyjskich na terytorium irańskie 25 sierpnia 1941 r. spotkało się z falą krytyki w Turcji. Rozgłośnie radiowe oraz wszystkie ważniejsze gazety tureckie potępiły akt pogwałcenia suwerenności Iranu (Deringil, 2004, s. 127. Tamkin, 2009, s. 56). Prezydent Turcji Ismet Inönü w rozmowie z Knatchbullem-Hugessenem wyraził swoje niezadowolenie, posuwając się nawet do stwierdzenia, że gdyby mógł wybierać, to wolałby niemiecką niż sowiecką okupację północnego Iranu (FO 371/30093/R 5036, k. 106). Jednocześnie propaganda III Rzeszy próbowała wykorzystać sytuację i przekonywała - jak donosił Knatchbull-Hugessen - nawet w pewnym stopniu skutecznie, że następną ofiarą żądań brytyjskich i sowieckich padnie Turcja (FO 371/30076/R 8358, k. 210). Najgorsze jednak, że zaufanie do Brytyjczyków ponownie zostało nadszarpnięte w tureckich sferach rządowych. Ambasador brytyjski, działając z polecenia Edena, cały czas zaręczał, że Wielka Brytania nie zamierza uczynić nic poza uzyskaniem zgody od Teheranu na wydalenie Niemców z terytorium Iranu. Dopiero w ostatniej chwili miał poinformować rząd turecki, że w celu ochrony własnych interesów Związek Sowiecki i Wielka Brytania zostali zmuszeni do tymczasowej okupacji Iranu (FO 371/30093/R 7875, k. 86). Tymczasem Turcy doskonale zdawali sobie sprawę z faktu, że Brytyjczycy planują interwencję zbrojną w Iranie. Na dwa dni przed interwencją Knatchbull-Hugessen informował, że władze w Ankarze rozważają udzielenie pomocy materiałowej rządowi irańskiemu w przypadku wtargnięcia na jej terytorium Armii Czerwonej i wojsk brytyjskich (FO 371/30093/R 7908, k. 88).

Krótko mówiąc, Brytyjczykom nie udało się przekuć nawiązania współpracy ze Związkiem Sowieckim w atut w stosunkach z Turkami. Wręcz przeciwnie musieli skupić się na rozwianiu obaw Ankary. Mimo oświadczeń z 10 sierpnia nie udało im się osiągnąć sukcesu w tej materii. Brytyjsko-sowiecka interwencja w Iranie, przygotowana całkowicie za plecami Turcji, sprawiła, że władze tureckie coraz bardziej podejrzliwym okiem zaczęły spoglądać na działania Wielkiej 
Brytanii. Nie był to jednak jedyny punkt zapalny w relacjach między Londynem a Ankarą. Mniej więcej w tym samym czasie wróciła bowiem kwestia sprzedaży chromitu do III Rzeszy.

Podpisując układ o przyjaźni i nieagresji, Turcja i Niemcy zobowiązały się poprzez wymianę not do intensyfikacji kontaktów handlowych (Glasneck, Kircheisen, 1968, s. 89. Krecker, 1964, s. 176. Zdulski, 2009, s. 105). Dla tureckiej gospodarki była to duża szansa. Prawie dwa lata wojny pokazały, że Brytyjczycy nie są w stanie zastąpić Niemców jako głównych odbiorców produktów tureckich. Oczywiście negatywnie na rozwój stosunków handlowych między Turcją a Wielką Brytanią wpłynął fakt, że od połowy 1940 r. Morze Śródziemne stało się obszarem walk. Według statystyk na rok 1940 r. wywóz towarów do Wielkiej Brytanii wzrósł co prawda dwukrotnie, ale i tak stanowił tylko 10\% eksportu tureckiego. Oznaczało to, że Turcy musieli szukać nowych rynków zbytu, albowiem sprzedaż towarów do III Rzeszy spadła z 37\% do zaledwie 9\% udziału w eksporcie. Sztuka ta stronie tureckiej udała się tylko częściowo i w $1940 \mathrm{r}$. Turcy wyeksportowali o prawie $1 / 3$ mniej towarów niż w roku poprzednim (611 203 tony w porównaniu z 927696 tonami). Na szczęście dla Ankary pod względem finansowym sytuacja nie była katastrofalna, gdyż ze względu na sprzedaż wielu produktów po zawyżonych cenach strata wyniosła zaledwie niecałe 16 mln funtów tureckich (obrót spadł z 127389000 w 1939 do 111446 500). Co istotne największy wzrost eksportu nastąpił do takich państw jak: Włochy (z 10\% do 16\% udziału w rynku), Rumunia (z 1,4\% do 10,7\%), Węgry (z 1,2\% do 5,8\%), Szwajcaria (z 1,5\% do 4,5\%), Grecja (z 1,2\% do 3,9\%) oraz Jugosławia (z $0,2 \%$ do 3\%) (FO 424/286). Wszystkie te państwa oprócz Szwajcarii w połowie 1941 r. należały do obozu państw Osi i były kontrolowane lub okupowane przez Niemców. Oznaczało to, że de facto, dołączając do tego Czechosłowację, która ujęta została w statystykach za rok 1940, a przecież znajdowała się pod niemiecką okupacją (Protektorat Czech i Moraw) lub kontrolą (Słowacja), III Rzesza miała wpływ na prawie52\% eksportu tureckiego. Poza tym rozwojowi stosunków handlowych między III Rzeszą a Turcja sprzyjał fakt, że po zdominowaniu Europy Południowo-Wschodniej przez Niemców powstała możliwość funkcjonowania bezpiecznej linii dostaw towarów i surowców między tymi państwami. W tej sytuacji strona turecka mogła albo szukać nowych rynków zbytu, co biorąc pod uwagę dotychczasowe działania nie rokowało dobrze, albo znormalizować stosunki gospodarcze z nazistowskimi Niemcami.

Niemiecka delegacja handlowa przybyła do Turcji 7 września i od samego początku zaczęła naciskać na przywrócenie dostaw chromitu. W zamian 
kuszono stronę turecką dostawami sprzętu wojskowego (Glasneck, Kircheisen, 1968, s. 89-91. Krecker, 1964, s. 177, Zdulski, 2009, s. 106). Turcy spodziewali się takiej propozycji, ale jednocześnie zdawali sobie sprawę z faktu, że Brytyjczycy nie będą chcieli zgodzić się na taki obrót spraw. Z formalnego punktu widzenia porozumienie paryskie z 1940 r., w którym alianci zapewnili sobie prawo do wykupu tureckiego chromitu, obowiązywać miała tylko do końca 1941 r. Później rząd turecki uzyskiwał swobodę w kwestii dysponowania posiadanymi zapasami oraz bieżącym wydobyciem tego cennego surowca, $\mathrm{z}$ jednym jednak zastrzeżeniem. Mianowicie sygnatariusze, czyli Francja i Wielka Brytania, uzyskiwali pierwszeństwo do zakupu, jeżeli wyraziliby wolę przedłużenia postanowień układu z Paryża na następny rok (Inanç, 2006, s 908). W tej sytuacji Ankara podjęła grę, której celem było osiągnięcie porozumienia $\mathrm{z}$ obiema stronami konfliktu.

Już na początku lipca 1941 r. gen. Asim Gündüz, zastępca tureckiego szefa sztabu generalnego, poinformował adm. Howarda Kelly’ego, pełniącego funkcję specjalnego wysłannika admiralicji w Turcji, że możliwe jest zawarcie niemiecko-tureckiej umowy handlowej. Co prawda turecki minister spraw zagranicznych Sükrü Saraçoğlu zaprzeczył, jakoby miała być to prawda, lecz ziarno podejrzliwości zostało zasiane nad Tamizą. W Londynie zrozumiano, że jeśli nie zostaną podjęte żadne kroki, to Turcy wraz z nastaniem nowego roku rozpoczną sprzedaż chromitu III Rzeszy. W związku z tym poinstruowano Knatchbulla-Hugessena, że Wielka Brytania jest gotowa przedłużyć obowiązywanie porozumienia paryskiego do 8 stycznia 1943 r. (Robertson, 1986, s. 67).

Rząd turecki długo nie odpowiadał na propozycję brytyjską. Po upływie ponad miesiąca ambasador brytyjski wznowił naciski. Wówczas to Saraçoğlu poinformował swojego interlokutora, że Ankara nosi się z zamiarem przedłużenia umowy, ale jednocześnie chciałaby zachować 7 tys. ton do celów negocjacyjnych. Powołano się przy tym na jedną z klauzul porozumienia paryskiego, która umożliwiała wyeksportowanie takiej ilości do Włoch w 1940 r.. Ambasador brytyjski zdecydowanie zaprotestował przeciwko powyższej interpretacji, podkreślając, że była ona nie do pogodzenia $\mathrm{z}$ duchem układu, ponieważ zarezerwowana ilość finalnie trafiłaby do Niemców (FO 371/30083/R 7912). Strona turecka jednak nie ustępowała, a nawet zwiększyła swoje żądania. W drugiej połowie września, a więc w momencie, kiedy niemiecko-tureckie negocjacje handlowe były już w toku, zapewniono Brytyjczyków, że umowa na sprzedaż chromitu zostanie przedłużona na rok 1942, ale jednocześnie dano do zrozumienia, że rząd turecki chciałby zatrzymać do swojej dyspozycji $4 / 15$ wydobycia, a więc 
część, która zgodnie z umową paryską przysługiwała Francji (FO 371/30083/R 8537). W Londynie zawrzało. Eden wezwał ambasadora tureckiego Rüstü Arasa i ostrzegł go, że kwestia chromitu jest dla Wielkiej Brytanii oznaką dobrej woli Turcji względem przymierza brytyjsko-tureckiego. Zwrócił przy tym uwagę, że nie chodzi tyle o sam akt sprzedaży niedużej bądź co bądź ilości tego surowca, ile o zasady moralne. Jak bowiem można było wytłumaczyć brytyjskiej opinii publicznej fakt, że rząd turecki udostępni wrogom materiał do wyrobu sprzętu wojskowego, który później będzie służył do zabijania brytyjskich żołnierzy (FO 424/286, s. 84-86)?

Odwołanie się do tureckiego poczucia honoru mogło okazać się jednak zbyt słabym argumentem, aby wpłynąć na postawę Ankary. Alternatywą mogły być nowe dostawy sprzętu wojskowego. W ten sposób Brytyjczycy mogliby zneutralizować ofertę niemiecką i przechylić szalę na własną korzyść. Nie należało lekceważyć tego czynnika, tym bardziej że w tym samym czasie, podczas trwających konsultacji między attaché wojskowymi w Ankarze a tureckim sztabem generalnym, marszałek Fevzi Çakmak wysunął prośbę o przekazanie samolotów bojowych oraz broni pancernej dla tureckich sił zbrojnych (FO 371/30029/R 8224).

Nad Tamizą rozważano taką opcję. W związku z tym, że na ukończeniu znajdowały się okręty, które pierwotnie zamówione przez Turcję zostały przejęte przez Royal Navy, w FO pojawiła się propozycja, aby przekazać je stronie tureckiej. Jednak w wyniku konsultacji między Ministerstwem Skarbu (Treasury) a Ministerstwem Wojny Gospodarczej (Ministry of Economic Warfare) pomysł ten został odrzucony. Zastanawiano się również nad spełnieniem części żądań przedstawionych przez marszałka Çakmaka. W tym względzie istniały jednak niewielkie szanse na ich realizację. Ministerstwo Lotnictwa $\mathrm{z}$ miejsca odrzuciło możliwość dostarczenia dla tureckich sił powietrznych bombowców, a z kolei Kwatera Główna na Bliskim Wschodzie tłumaczyła się, że nie będzie w stanie przekazać żadnych myśliwców poza tymi, które jeszcze w lutym zostały obiecane stronie tureckiej (FO 371/30029/R 8550).

Jak widać, w Londynie nie potrafiono zdecydować się na żadną konkretną ofertę. Każdy pomysł napotykał obiekcje wysuwane jak nie przez jeden, to przez inny resort. Najbliżej realizacji była propozycja przedstawiona przez FO, ale ciągle brakowało decyzji w kwestii jej implementacji, a tymczasem negocjacje niemiecko-tureckie wchodziły powoli w decydującą fazę. W tej sytuacji adm. Kelly, działając bez upoważnienia, poinformował Ankarę, że zamówione przez nią cztery niszczyciele i cztery łodzie podwodne zostaną wysłane do wschodniej 
części Morza Śródziemnego, przy czym po jednym okręcie z każdej klasy Turcy otrzymają od razu, a pozostałe po sześciomiesięcznej służbie w Royal Navy. Krok ten podważył ustalenia podjęte przez Ministerstwo Skarbu i Ministerstwo Wojny Gospodarczej, jak również spotkał się z krytyką zarówno pierwszego lorda admiralicji A.V. Alexandra. Mimo to uznano, że wycofanie się z tej obietnicy przyniesie więcej szkody niż pożytku, a zatem gabinet wojenny został postawiony przed faktem dokonanym i tym samym zmuszony do zaakceptowania tego stanu rzeczy (CAB 65/19/34, s 63). W końcu co prawda udało się wypracować plan dotyczący dostaw materiałów wojennych dla armii tureckiej, ale nastąpiło to dopiero półtora miesiąca później. Został on poparty przez COS oraz zaaprobowany przez gabinet wojenny (CAB 65/20/8, s. 161). Co znamienne, nie uwzględniono w nim w ogóle sprzętu, na którego przekazanie nalegał marszałek Çakmak. Tłumaczono to tym, że Turcy nie są przygotowani do obsługi zaawansowanych rodzajów broni. Tym samym miano jasno dać do zrozumienia stronie tureckiej, że zamiast czołgów potrzebnych do stworzenia dywizji pancernej będą musiały wystarczyć jej brytyjskie oddziały pancerne, które przyjdą jej z pomocą w razie agresji. Dla armii tureckiej zamierzano przede wszystkim przeznaczyć materiały, które wzmocniłyby potencjał ich dywizji piechoty, dlatego w pierwszej kolejności miały to być karabiny bojowe, pistolety maszynowe, wyposażenie dla oddziałów inżynieryjnych, działa polowe i przeciwpancerne. Następnie środki transportu motorowego, których brak był piętą achillesową armii tureckiej. Odpowiednie zapasy surowców dla tureckich fabryk zbrojeniowych, produkujących amunicję oraz środki wzmacniające zaplecze sił zbrojnych, w tym m.in. wyspecjalizowany sprzęt, jak działa przeciwlotnicze (CAB 66/19/38, k. 193). O ile jednak propozycja adm. Kelly’ego mogła mieć jakiś wpływ na decyzję rządu tureckiego w kwestii dostaw chromitu, o tyle powyższy plan nie, ponieważ zaczął obowiązywać ponad miesiąc za późno.

W pierwszych dniach października Knatchbulla-Hugesssenowi przekazano, że Niemcy nie otrzymają nawet tony chromitu, dopóki przedłużony układ z Wielką Brytanią będzie w mocy, czyli do stycznia 1943 r. Później jednak pojawi się okres przejściowy, w którym Turków nie będą krępowały żadne zobowiązania i nie będą mogli odmówić Niemcom zakupu tego surowca. Jedyne, co Saraçoğlu był w stanie zaproponować, to podjęcie przez Brytyjczyków próby wykupienia jak największej ilości tego surowca (FO 371/30084/R 8839). 9 października 1941 r. Turcy zawarli z delegacją niemiecką umowę handlową, na mocy której Ankara zobowiązała się m.in. do przekazania chromitu w zamian za sprzęt wojskowy. Transporty mogły ruszyć dopiero po 15 stycznia 1943 r. i nie miały 
przekroczyć 45 tys. ton. Jeżeli jednak Niemcy dostarczyliby obiecaną broń do 31 marca 1943 r., to mogli się starać o dodatkowe 135 tys. ton tej rudy, przy czym nie więcej niż 90 tys. rocznie, o ile gotowi byliby podpisać nowe kontrakty na dostawy materiałów wojennych dla Turcji (Glasneck, Kircheisen, 1968 s. 93. Krecker, 1964, s. 180).

W Londynie pogodzono się z tym faktem bez większych emocji. Eden, komentując całą sprawę, stwierdził, że „rozwiązanie problemu chromitu nie jest satysfakcjonujące, ale mogło być znacznie gorzej” (CAB 65/19/37, s. 82). Mimo to FO postanowiło nie składać broni. Skoro nie udało się storpedować zawarcia porozumienia dotyczącego sprzedaży chromitu do Niemiec, to trzeba było zrobić wszystko, aby w ciągu następnego roku przejąć wszystkie zapasy tej rudy i zmusić Niemców do korzystania tylko z bieżącego wydobycia. Ambasada zajęła się zorganizowaniem dodatkowych transportów kolejowych, co zresztą zostało uwieńczone sukcesem. Z kolei Kierownictwo Operacji Specjalnych (Special Operation Executive - SOE) przekupiło pracowników bliżej nieznanego przedsiębiorstwa z Fetiye, którzy zobligowali się do zaprzestania wydobycia w należących do niej kopalniach (Robertson, 1986, s. 73).

Plany te o mało jednak nie zostały pokrzyżowane. Pod koniec listopada sekretarz stanu w tureckim ministerstwie spraw zagranicznych poinformował Knatchbulla-Hugessena, że Brytyjczycy będą mogli zakupić zapasy chromitu zgromadzone tylko do końca 1941 r. oraz wydobycie do 8 stycznia 1943 r., przy czym w tym drugim przypadku tylko do poziomu umożliwiającego zabezpieczenie 45 tys. ton dla III Rzeszy (FO 371/30086/R 10031). Jednak dwa dni później Ankara wycofała to oświadczenie. Jedynym ograniczeniem miała być utrata prawa do pierwszeństwa transportu po 8 stycznia 1943 r. (FO 371/30086/R 10140). Jak słusznie zauważył ambasador brytyjski w Ankarze, zapis ten nie kolidował specjalnie z działaniami na rzecz wyczyszczenia magazynów z zapasów chromitu (FO 371/30086/R 10558).

Z końcem roku doszło do wydarzenia, które miało olbrzymi wpływ na dalszy przebieg II wojny światowej. 7 grudnia 1941 r. Japonia zaatakowała z zaskoczenia amerykańska bazę w Pearl Harbour. Cztery dni później Niemcy i Włochy wypowiedziały Stanom Zjednoczonym wojnę. Tym samym obóz aliantów zyskiwał potężnego sojusznika o olbrzymich możliwościach mobilizacyjnych oraz prawie nieograniczonych gospodarczych. W perspektywie długofalowej sojusz ze Stanami Zjednoczonymi stawał się atutem w rękach Brytyjczyków. Dla bieżącej polityki brytyjskiej sprawa nie była tak jednoznaczna. Turcy wyrażali raczej zaniepokojenie niż entuzjazm. Minister spraw zagranicznych w rozmowie 
z ambasadorem brytyjskim, podsumowując rozwój wydarzeń polityczno-militarnych do schyłku 1941 r., nie omieszkał zwrócić uwagi na ciężką sytuację aliantów na Pacyfiku i w Azji Wschodniej (FO 371/30094/R 10883). Z kolei gen. Gündüz wyraził opinię, że front dalekowschodni nie powinien odciągać uwagi brytyjskiej od głównego, czyli europejskiego teatru wojny (FO 371/30094/R 10509). Można zaryzykować stwierdzenie, że przystąpienie Stanów Zjednoczonych do wojny, co wiązało się z uwikłaniem Wielkiej Brytanii w konflikt zbrojny z Japonią w krótkiej perspektywie nie wzmocnił, lecz osłabił możliwości oddziaływania Wielkiej Brytanii na Turcję. Poza tym odpadał argument udzielenia wsparcia materiałowego ze strony Stanów Zjednoczonych. Turcja została bowiem objęta dostawami w ramach Lend-Lease Act już pod koniec marca $1941 \mathrm{r}$. W ciągu kilku pierwszych miesięcy Amerykanie dostarczyli 50 haubic wraz z amunicją oraz 10 ciężarówek, co było kroplą w morzu potrzeb tureckich sił zbrojnych, a zatem nie mogło wpłynąć na postawę rządu w Ankarze (Foreign Relations of the United States, dalej: FRUS, 1941: t. III, 1959, s. 930-931).W końcu należy zwrócić uwagę, że przystąpienie Stanów Zjednoczonych do wojny w kontekście relacji na linii Ankara-Londyn znalazło się w cieniu stosunków pomiędzy Wielką Brytanią a Związkiem Sowieckim.

Wizyta Edena w Moskwie w grudniu 1941 r. wywołała silne zaniepokojenie dyplomacji tureckiej. Aras pisał z Londynu, że Wielka Brytania i Stany Zjednoczone są w gorszej sytuacji negocjacyjnej niż Związek Sowiecki, ponieważ od czasu ataku na Pearl Harbor znajdują się pod ciągłym naciskiem wojsk japońskich. Poza tym w Afryce Północnej pomimo ofensywy brytyjskiej przełomu nie było, w przeciwieństwie do frontu wschodniego, gdzie zatrzymano niemieckie uderzenie na Moskwę. Następnie ostrzegał, że w tej sytuacji należy przygotować się na podjęcie przez stronę sowiecką kwestii, które w sposób bezpośredni lub pośredni będą dotyczyć Turcji. Z kolei turecki ambasador w Moskwie przewidywał, że rozmowy te dotyczyć będą „nowego porządku światowego”, co biorąc pod uwagę sowieckie koncepcje polityczne, mogło okazać się bardzo niebezpiecznym eksperymentem (Tamkin, 2009, s. 108-109).

Londyn oczywiście zdawał sobie sprawę z obaw tureckich, podsycanych dodatkowo jeszcze przez niemiecką propagandę, która rozpowiadała, że podczas konferencji moskiewskiej Brytyjczycy zgodzili się dać wolną rękę Sowietom w północnym Iranie i Turcji oraz obiecali im kontrolę na cieśninami czarnomorskimi (Robertson, 1986, s. 83).W tej sytuacji starano się uspokoić Ankarę. Eden jeszcze przed wyjazdem z Moskwy wysłał instrukcje do ambasadora w Turcji, że strona sowiecka nie podniosła kwestii tureckiej, a w momencie kiedy szef FO 
podjął ten wątek, wykazała ona bardzo przyjazną postawę (Woodward, 1975, s. 82).

Faktycznie w trakcie rozmów moskiewskich Stalin nie przedstawił żadnych żądań względem Turcji. Eden podczas obrad gabinetu wojennego określił jego podejście jako „rozsądne”. Dodał przy tym, że przywódca Związku Sowieckiego przywiązywał duże znaczenie do zachowania neutralności przez Turcję, ze względu na pełnioną przez nią funkcję bariery, a nawet był gotów przekupić Ankarę, żeby ta zachowała neutralność (CAB 65/29/1, k. 4). W tej materii jego propozycja obejmowała nabytki terytorialne. W pierwszej kolejności stwierdził, że do państwa tureckiego powinny zostać przyłączone Wyspy Dodekanezu. Na uwagę Edena, że są one zamieszkałe w większości przez ludność grecką, odparł, że Turcy również mieszkają na terenie Grecji, a poza tym można zaaranżować wymianę niektórych wysp na Morzu Egejskim między Grecją a Turcją. Poza tym uważał, że Turcja powinna otrzymać fragment Bułgarii, a mianowicie obszar na południe od Burgas, który zamieszkały był przez ludność turecką. Wreszcie jego zdaniem można było zgodzić się na przyłączenie terenów północnej Syrii do państwa tureckiego (CAB 66/20/39, k. 196, 197, 200-201, 203).

Uwagi Stalina były bardzo niewygodne dla Brytyjczyków, gdyż mogły doprowadzić do niepotrzebnych napięć. Londyn nie mógł zgodzić się na przekazanie Turcji części północnej Syrii, ponieważ po interwencji we francuskim Lewancie uznał niepodległość i integralność terytorialną Syrii i Libanu. Z kolei kwestia archipelagu Dodekanezu mogła wywołać silne protesty ze strony emigracyjnego rządu greckiego. Ujawnienie tych informacji rządowi tureckiemu też nie wchodziło w grę, albowiem Londyn musiałby się przyznać, że nie może ich poprzeć, co mogło negatywnie odbić się na relacjach z Ankarą. Z tego też względu Brytyjczycy byli bardzo wstrzemięźliwi w przekazywaniu wiadomości dotyczących rozmów moskiewskich (FO 371/33340/R 316, s. 35-36).

Starania w celu ukrycia szczegółów wizyty moskiewskiej nie powiodły się, gdyż na początku drugiej połowy stycznia ambasador sowiecki w Ankarze przekazał Turkom relację z rozmów między Edenem i Stalinem, w której znalazły się wszystkie propozycje sowieckie. Saraçoğlu od razu zawezwał Knatchbulla-Hugessena i poprosił go o wyjaśnienia. Dyplomata brytyjski był w stanie jedynie skomentować, że teraz minister spraw zagranicznych powinien zrozumieć, na czym szef FO oparł swoje przekonanie, że przywódca Związku Sowieckiego pragnie istnienia silnej Turcji (FO 371/33340/R 451, s. 83).

Po raz kolejny okazało się, że Londyn nie był szczery z Ankarą w kwestii współpracy brytyjsko-sowieckiej. Ponadto tym razem Brytyjczycy pozostawili 
po sobie gorsze wrażenie niż strona sowiecka, która okazała się adwokatem interesów tureckich, mimo że rolę tę powinna odgrywać Wielka Brytania. Jednak Moskwa nie cieszyła się długo swoim osiągnięciem. 24 lutego został zorganizowany zamach bombowy na ambasadora niemieckiego w Turcji, Franza von Papena. Śledztwo szybko wykazało, że wśród osób wplątanych w tę aferę było dwóch obywateli Związku Sowieckiego. Problem polegał na tym, że schronili się oni na terenie sowieckiego konsulatu w Stambule, który został otoczony przez policję. Po naciskach na dyplomatów obaj podejrzani zostali wydani (Hassel, MacRae, 2008, s. 191-193). Całe zajście oraz późniejszy proces sądowy wywołały kryzys w relacjach na linii Moskwa-Ankara. Prasa sowiecka przypuściła silne ataki zarówno na system prawny w Turcji, jak i rząd turecki. Aktay pisał, że cała sprawa może skończyć się zerwaniem przez Związek Sowiecki stosunków dyplomatycznych z Turcją (Tamkin, 2009, s. 110).

Brytyjczycy próbowali łagodzić napięcie, ale de facto byli tylko obserwatorami w tej sprawie (FO 371/33340/R 2073, s. 129). Londyn stawiało to w niezręcznym położeniu, ponieważ niebawem miały rozpocząć się brytyjsko-sowieckie negocjacje dotyczące zawarcia politycznego i wojskowego układu sojuszniczego. Wiadomo było, że przy tej okazji w Turcji nasilą się obawy dodatkowo jeszcze spotęgowane przez kryzys wywołany aferą bombową. W związku z powyższym Eden przedstawił plan, mający uspokoić rząd turecki. Proponował, aby przed podpisaniem układów Moskwa i Londyn wydały deklaracje, w których tłumaczono by, że ich zawarcie jest potrzebne do osiągnięcia wspólnego celu, jakim było pokonanie III Rzeszy. Następnie potwierdzono by zobowiązania zawarte w oświadczeniach z 10 sierpnia 1941 r., czyli brak jakichkolwiek wrogich zamiarów względem cieśnin czarnomorskich, poszanowanie konwencji z Montreux, nienaruszalność integralności terytorialnej Turcji oraz udzielenie wszelkiej pomocy w przypadku agresji (CAB 66/23/24, k. 104).

Propozycja Edena została zaakceptowana przez gabinet wojenny, a następnie przedstawiona stronie sowieckiej. Pomimo że ostatecznie nie doszło do podpisania osobnego układu politycznego, lecz jedynie sojuszu wojskowego, to zarówno Londyn, jak i Moskwa przekazały deklarację o opisanej wyżej treści Ankarze (FO 371/33341/R 3494, s. 37).

Zapewnienia te, mimo że potrzebne, nie wyeliminowały całkowicie podejrzeń decydentów znad Bosforu. W kręgach tureckiej dyplomacji nadal trwały spekulacje na temat ceny, jaką Brytyjczycy musieli zapłacić za współpracę ze Związkiem Sowieckim. Nowy ambasador w Londynie Rauf Orbay pisał, że skoro 
Wielka Brytania poświęciła państwa bałtyckie, to również dobrze może to samo uczynić z interesami Turcji (Tamkin, 2009, s. 112).

Taki stan rzeczy mógł w dłuższej perspektywie doprowadzić do opłakanych skutków. Podczas jednego z czerwcowych zebrań gabinetu wojennego szef FO ostrzegł, że Niemcy z pewnością wykorzystają tureckie podejrzenia wobec intencji Moskwy (CAB 65/26/33, s. 66). Było to o tyle groźne, że w tym samym czasie doszło do intensyfikacji kontaktów między Ankarą a Berlinem. Od ostatniej dekady maja 1942 r. w Niemczech przebywała delegacja turecka, która zamierzała wynegocjować nową umowę na zakup sprzętu wojskowego. Do III Rzeszy zaproszono również tureckich wysokich rangą oficerów oraz dziennikarzy. Ponadto doszło do otwarcia linii kolejowych pomiędzy Bułgarią i Turcją co sprzyjało wzrostowi niemiecko-tureckich kontaktów handlowych (Glasneck, Kircheisen, 1968, s. 96-97, Krecker, 1964, s. 181-182).

Brytyjczycy wiedzieli dobrze, że Niemcy zaproponowali stronie tureckiej sprzedaż czołgów, a więc ten rodzaj sprzętu, którego dostawy zgodnie z przyjętym nad Tamizą planem z listopada 1941 r. odrzucono. Tymczasem strona turecka ponawiała prośby w tym względzie. Już pod koniec stycznia Inönü w rozmowie $\mathrm{z}$ attaché wojskowym podkreślał, że tureckie siły zbrojne będą potrzebowały przede wszystkim broni pancernej oraz samolotów bojowych, jeżeli mają mieć jakąkolwiek szansę w powstrzymaniu niemieckiego ataku. Komentując tę prośbę Knatchbull-Hugessen starał się przekonać Londyn, że należy zmienić nastawienie i zgodzić się na przynajmniej symboliczne dostawy tego rodzaju sprzętu, gdyż inaczej sprawa ta może nabrać politycznego zabarwienia (FO 371/33338/R 706). $\mathrm{Z}$ oceną ambasadora w Turcji zgodził się marszałek Charles Portal, szef sztabu RAF-u. Jego zdaniem przekazanie dużej liczby dział przeciwpancernych, przeciwlotniczych oraz czołgów, niezależnie od tego, czy Turcy byli w stanie wykorzystać je skutecznie, czy nie, wzmocniłoby na pewno turecką wolę oporu. Opinię tę poparł szef Imperialnego Sztabu Generalnego, gen. Alan Brooke. Przeciwny był natomiast Eden, który zgodnie ze swoją wcześniejszą rekomendacją uważał, że zaawansowany technicznie sprzęt powinien być obsługiwany jedynie przez żołnierzy brytyjskich, a Turkom co najwyżej można przekazać symboliczne ilości, aby nie urazić ich dumy (Prime Minister's Office files, dalej: PREM, 3/445/8, s. 38). Londyn nie był w stanie wypracować jednolitego stanowiska w tej sprawie, a tymczasem na początku kwietnia 1942 r. Turcy poprzez ambasadora w Londynie ponowili prośbę o dostawy sprzętu wojskowego, zawężając tym razem swoje wymagania tylko do najbardziej potrzebnych dział przeciwpancernych i przeciwlotniczych (FO 371/33362/R 2343). 
Do tego momentu kwestia dostaw broni miała znaczenie praktycznie tylko wojskowe. Kiedy jednak na początku maja Niemcy zaproponowali stronie tureckiej rozpoczęcie rozmów na temat nowych kontraktów na sprzęt wojskowy, stało się to, co przewidział Knatchbull-Hugessen, a mianowicie sprawa nabrała wymiaru politycznego. FO początkowo nie było w stanie przedstawić żadnej konkretnej kontroferty. Jedyny pomysł, jaki się pojawił w tym resorcie, dotyczył przekazania Turkom francuskiej artylerii i amunicji przejętych po zajęciu przez Brytyjczyków Syrii i Libanu (FO 371/33330/R 2379). Z kolei Brooke zaproponował wysłanie do Turcji 3000 sztuk 29-mm przeciwpancernych moździerzy trzonowych, tzw. bombard Blackera (CAB 80/36, s. 153). Obie propozycje były mało atrakcyjne. Artyleria $\mathrm{z}$ arsenałów francuskich pamiętała jeszcze czasy I wojny światowej, a bombarda Blackera nie była sprzętem pierwszej klasy, o czym najlepiej świadczy fakt, że poza kilkoma wyjątkami nie używały jej jednostki brytyjskiej armii regularnej. Ofertę z prawdziwego zdarzenia z kolei zaproponował Churchill, aczkolwiek jej realizacja miała nastąpić dopiero późną jesienią i zimą. W tym czasie zdaniem brytyjskiego premiera działania na froncie wschodnim ze względu na warunki pogodowe miały ustać i do Związku Sowieckiego nie będzie trzeba wysyłać tak licznych transportów z materiałami wojennymi. Zaoszczędzony w ten sposób sprzęt oraz statki do jego przewozu będzie można wykorzystać do dostarczenia Turcji odpowiednio dużej ilości broni. Dokładnie rzecz ujmując, miał on na myśli 1000 czołgów oraz tyle samo dział przeciwpancernych i przeciwlotniczych (FO 371/33339/R 3225). Pomimo pewnych oporów FO zaakceptowało propozycję Churchilla (FO 371/33339/R 3742). Problem jednak polegał na tym, że Brytyjczycy nie byli w stanie sami wygospodarować takiej ilości sprzętu wojskowego. W związku z czym postanowiono poprosić o udział w tym projekcie Amerykanów. Do początku czerwca FO przygotowało list do Franklina Delano Roosevelta, który osobiście dostarczyć miał Churchill podczas swojego pobytu w drugiej połowie czerwca w Stanach Zjednoczonych (CAB 79/21/29, s. 300). Amerykanie zgodzili się i już od lipca miały ruszyć pierwsze dostawy zarówno czołgów, jak i dział przeciwpancernych. Niestety, pod względem ilościowym rozmiar zaangażowania amerykańskiego był mniejszy, niż się spodziewano. Do końca roku obiecano wysłać 170 lekkich czołgów Stuart oraz 400 dział ppanc. (War Office, dalej: WO 106/3195). Oznaczało to, że sporą część obciążeń Brytyjczycy musieli wziąć na własne barki, co nie mogło przypaść do gustu WO.

Tymczasem Turcy zapewnili Brytyjczyków, że z oferty niemieckiej o wartości 400 mln marek maksymalnie zaakceptują sprzęt za nie więcej niż 100-110 mln marek. Mimo wszystko tak duże zakupy wymagały zaciągnięcia kredytu w wyso- 
kości całej tej kwoty. Ponadto do Londynu zaczęły przenikać informacje, że Niemcy omawiają ze stroną turecką sposoby, które umożliwiłyby zakup sprzętu powyżej tej kwoty prawdopodobnie na zasadzie barteru. Informacje te były bardzo niepokojące. Eden zwrócił uwagę, że dotychczasowa pomoc brytyjska nie będzie mogła równać się z negocjowaną niemiecką. Przypomniał, że z kredytu brytyjsko-francuskiego na dostawy broni, podpisanego w 1939 r., opiewającego na $25 \mathrm{mln}$ funtów, do tej pory z winy aliantów została wyczerpana tylko połowa środków. Z kolei negocjowany kredyt niemiecki będzie mógł być zrealizowany w ciągu pół roku. Oznaczało to, że jeśli Niemcy wypełniliby swoją obietnicę, to dostarczyliby w jednej szóstej czasu trzy razy więcej broni niż Brytyjczycy (CAB 66/26/34, k. 155).

Pesymistyczny wydźwięk raportu szefa FO nie przekonał sceptycznie nastawionych do projektu Churchilla sztabowców brytyjskich. Przede wszystkim podkreślano niedobory czołgów w bliskowschodnim teatrze operacyjnym ( 850 sztuk), zobowiązania wobec jednostek sojuszniczych (szczególnie wyposażenie wojsk polskich oraz przezbrojenie oddziałów pancernych w dwóch dywizjach południowoafrykańskich), zwracano uwagę, że spora część maszyn znajduje się w warsztatach remontowych, argumentowano, że amerykańskie czołgi lekkie będą lepiej nadawały się do akcji na terenie Iraku lub Iranu niż Turcji itd. (WO 106/3195. WO 216/25). Po długotrwałych wymianach argumentów Churchillowi udało się w końcu postawić na swoim i pod koniec września mógł przekazać ambasadorowi tureckiemu listę sprzętu wojskowego, który miał zostać dostarczony zarówno do końca 1942 r., jak i w późniejszym terminie. Oprócz czołgów, dział przeciwpancernych i przeciwlotniczych znalazły się na niej również wyposażenie dla jednostek piechoty, takie jak: działa polowe, ręczne karabiny maszynowe, lekkie karabiny maszynowe, pistolety maszynowe, moździerze oraz karabiny przeciwpancerne. $\mathrm{W}$ trzech pierwszych kategoriach obiecano przesłać 410 lekkich czołgów amerykańskich do końca 1942 r., a następnie kolejne 170 sztuk, 200 ciężkich czołgów typu Valentine lub Matilda, 746 dział przeciwpancernych kal. $37 \mathrm{~mm}$, a kolejne 236 później oraz 97 dział przeciwlotniczych. Łącznie zamierzano przekazać 780 czołgów oraz 1077 dział przeciwlotniczych i przeciwpancernych (CAB 66/29/10, k. 32).

Oferta brytyjska, a właściwie brytyjsko-amerykańska, została przyjęta przez stronę turecką przychylnie. Nie oznaczało to jednak, że Turcy zamierzali zrezygnować z zakupu broni z III Rzeszy. W grudniu ostatecznie zaakceptowano kredyt i podpisano kontrakt na dostawy niemieckich materiałów wojennych, które objęły 60 dział przeciwpancernych kal. $50 \mathrm{~mm}$, wraz z zapasem 50 tys. 
sztuk amunicji, 265 ciężkich karabinów maszynowych (SMG 34) z ponad 21 mln pocisków, 32 czołgi Panzer III, 35 czołgów Panzer IV, 3 czołgi dowodzenia, 70 myśliwców Focke Wulf 190 oraz sprzęt optyczny (Krecker, 1964, s. $264-270)$.

Perspektywa zawarcia nowej niemiecko-tureckiej umowy na zakup sprzętu wojskowego, która pojawiła się w maju 1942 r., oznaczała, że coraz bardziej realne stawało się wejście w życie dodatkowych ustaleń niemiecko-tureckiego porozumienia w sprawie chromitu. Oznaczało to, że w ciągu dwóch lat III Rzesza będzie mogła wywieść z Turcji 180 tys. ton tego surowca. Zapewnienie sobie tych dostaw było sprawą najwyższej wagi dla niemieckiej gospodarki wojennej, gdyż wraz z końcem 1942 r. miały zostać wyczerpane zapasy tej rudy. Roczne zapotrzebowanie dla niemieckiego przemysłu zbrojeniowego wynosiło około 215 tys. ton, z czego z obszarów przez siebie kontrolowanych Niemcy byli w stanie pozyskać około 140 tys. ton. Zgodnie z porozumieniem z $1941 \mathrm{r}$. Niemcy mieli uzyskać od Turcji 45 tys. ton tego surowca, co oznaczałoby, że do niezbędnego minimum brakowałoby im nadal 30 tys. ton. Zgodnie jednak z postanowieniami dodatkowymi w przypadku zawarcia nowej umowy na sprzedaż broni III Rzesza miała otrzymać w 1943 r. kolejne 45 tys. ton (PREM 3/445/8, s. 3).

Brytyjczycy zdawali sobie sprawę z powagi sytuacji. Poza tym chromit turecki miał coraz większe znaczenie również dla aliantów. Jego część, którą Brytyjczycy odsprzedawali Amerykanom, pozwalała zrównoważyć stratę, jaką było zajęcie przez Japończyków głównego amerykańskiego źródła tego surowca, czyli Filipin. Biorąc pod uwagę fakt, że wydobycie chromitu w Turcji spadło do zaledwie 100 tys., to w przypadku wejścia w życie dodatkowych postanowień porozumienia niemiecko-tureckiego praktycznie nic nie pozostawałoby dla aliantów.

W pierwszej połowie września $1942 \mathrm{r}$. Knatchbull-Hugessen informował Londyn, że Niemcy i Turcy są bliscy porozumienia, aby negocjowany kredyt na zakupy broni został uznany za wypełnienie dodatkowych warunków porozumienia w sprawie chromitu z 1941 r. Poza tym strona niemiecka proponowała bardzo wysoką cenę - 270 funtów tureckich za tonę, co prawie dwukrotnie przewyższało cenę płaconą przez Brytyjczyków (140 funtów tureckich za tonę). Tym samym pojawiła się obawa, że Turcy będą próbowali obejść postanowienia umowy podpisanej w grudniu 1941 r. i sprzedać część zapasów za wyższą cenę, jak tylko układ z Wielką Brytanią przestanie obowiązywać (FO 371/33349/R 6049). Niejako potwierdzeniem tych obaw była przeprowadzona kilka dni później rozmowa z Saraçoğlu, który stwierdził, że o ile brytyjskie prawo do zakupu chromitu do stycznia 1943 r. jest jak najbardziej uzasadnione, to po tym terminie 
nie będzie można zmuszać producentów do sprzedaży tej rudy po niższej cenie (FO 371/33349/R 6309).

W tej sytuacji Ministerstwo Skarbu, Ministerstwo Wojny Gospodarczej oraz FO zgodziły się na pewne ustępstwa, ale jednocześnie wysunięto żądania mające zabezpieczyć wypełnienie przez Turków dotychczasowej umowy. Godzono się na zakup bieżącego wydobycia po cenie zaoferowanej przez Niemców, ale tylko pod warunkiem ujawnienia przez Ankarę wszystkich zapasów chromitu. Ponadto domagano się równego traktowania $\mathrm{z}$ Niemcami co do zakupów chromitu w 1943 i 1944 r. (FO 371/33350/R 6337).

Knatchbull-Hugessen przekazał stanowisko brytyjskie stronie tureckiej w ostatnich dniach września, wyliczając jednocześnie prawa brytyjskie do całego wydobycia chromitu za 1942 r. W odpowiedzi usłyszał od Saraçoğlu, że będzie musiał się on skonsultować ze swoimi doradcami prawnymi (FO 371/33332/R 6507). Był to już jasny sygnał, że część zobowiązania wobec Niemców rząd turecki będzie chciał pokryć z wydobycia za rok 1942.

W ciągu następnych dwóch miesięcy FO wspierane przez administrację amerykańską wywierało presję na stronę turecką, aby ta z jednej strony wypełniła warunki podpisanej przed rokiem umowy, a z drugiej zagwarantowała równouprawnienie zakupów w następnych dwóch latach (FRUS, 1942: t. IV, s. 748-49). Wobec już wcześniej wyrażonego sprzeciwu Churchilla nie można było jednak wykorzystać jako karty przetargowej planu dotyczącego zwiększenia dostaw broni (Woodward, 1975, s. 98). Niemcy nie mieli takich skrupułów i byli gotowi zagrozić anulowaniem kredytu na zakup sprzętu wojskowego.

Ostatecznie FO nie udało się dopiąć swego, mimo że przestano naciskać na równe traktowanie $\mathrm{z}$ Niemcami w ciągu następnych dwóch lat i skoncentrowali się tylko na wykupieniu dotychczasowego wydobycia i zapasów (FO 371/33385/R 6547). Co prawda strona turecka zgodziła się sprzedać Brytyjczykom cały chromit wydobyty do 8 stycznia 1943 r., przy czym ten po 25 września miał zostać sprzedany po zawyżonej cenie, ale zarezerwowano 45 tys. ton w związku potrzebą spełnienia zobowiązań wobec Niemiec. Poza tym III Rzesza miała uzyskać priorytet, jeżeli chodzi o zakupy w 1943 i 1944 r. (FO 371/33353/R 8548). 31 grudnia podpisano umowę, zgodnie z którą Wielka Brytania mogła do 31 grudnia 1944 r. skupować od Turcji chromit poza ilościami zarezerwowanymi w umowach zawartych lub planowanych (Inanç, 2006, s. 912).

Okres pomiędzy atakiem na Związek Sowiecki a klęskami niemieckimi na froncie wschodnim i w Afryce Północnej jesienią 1942 r., pomimo że długi pod względem chronologicznym, charakteryzował się najniższą dynamiką polityki 
zagranicznej Wielkiej Brytanii wobec Turcji od 1939 r. De facto dyplomacja brytyjska musiała zmierzyć się z dwoma wyzwaniami. Pierwszym było zbliżenie między Niemcami i Turcją, zapoczątkowane zawartym 18 czerwca 1941 r. układem o przyjaźni i nieagresji, a drugim stosunek Ankary do współpracy brytyjsko-sowieckiej.

W pierwszym przypadku Londyn nie wykazał się większą aktywnością. Praktycznie nie podjęto żadnej inicjatywy mającej przeciwdziałać temu procesowi. Wyjątkiem była propozycja Edena z końca czerwca 1941 r. o wymianie deklaracji na temat nienaruszalności interesów obu państw. W pozostałych przypadkach reagowano tylko na ewentualne kroki podejmowane przez Berlin.

W kwestii chromitu, dopóki III Rzesza nie wyraziła chęci zakupu tego ważnego surowca, dopóty nad Tamizą nie wykazywano zainteresowania tym tematem. Wydaje się to tym bardziej dziwne, że wraz z upływem 1941 r. kończył się okres obowiązywania porozumień paryskich, dzięki którym Brytyjczycy mogli w przez dwa lata wywozić całe wydobycie tureckiego chromitu. Zamiast zająć się sprawą jak najszybciej, FO zwlekało. Nie wykluczone, że liczono na zapis umożliwiający przedłużenie umowy na kolejny rok. Koniec końców dzięki niemu uzyskano monopol na zakup tej rudy na $1942 \mathrm{r}$. Jednak pozostawienie swobody ruchu przeciwnikowi sprawiło, że Brytyjczykom nie udało się już storpedować porozumienia, dzięki któremu Niemcy zapewnili sobie zaopatrzenie w chromit na lata 1943 i 1944.

Podobnie rzecz miała się z dostawami sprzętu wojskowego, który to problem notabene był powiązany ze sprzedażą chromitu. Zgodnie z memorandum Edena z jesieni 1941 r. Londyn postanowił nie dostarczać armii tureckiej czołgów, czyli sprzętu, o który proszono. W zamian oferowano wyposażenie dla dywizji piechoty. Pomimo ponawiających się próśb Brytyjczycy trwali na swoich pozycjach, chociaż pojawiły się głosy, zarówno z placówki dyplomatycznej w Ankarze, jak i w WO, że stanowisko to powinno zostać zrewidowane. Dopiero perspektywa rozpoczęcia negocjacji niemiecko-tureckich dotyczących kredytu na zakup broni w III Rzeszy sprawiła, że premier brytyjski zdecydował się wziąć sprawy w swoje ręce i był gotowy zaoferować Ankarze przekazanie 1000 czołgów. Ze względu jednak na oponentów oraz potrzebę uzyskania wsparcia amerykańskiego Churchillowi udało się zrealizować swój pomysł dopiero pod koniec września, kiedy to wręczył ambasadorowi tureckiemu listę sprzętu wojskowego, który miano przekazać armii tureckiej do końca 1942 r. Fakt ten nie wpłynął jednak na decyzję rządu tureckiego, który zdecydował się zaakceptować niemiecki kredyt, aczkolwiek w niższym wymiarze, niż początkowo proponował Berlin. Co 
istotne, III Rzesza w ten sposób zabezpieczyła sobie większe dostawy chromitu niż początkowo przewidywało to porozumienie z października $1941 \mathrm{r}$. Tym samym Londyn nie tylko musiał pogodzić się z faktem, że Niemcy rzutem na taśmę zyskali niezbędne minimum tego surowca do funkcjonowania niemieckiej gospodarki, ale dodatkowo zostali pozbawieni części dostaw.

Zaoferowanie pomocy przez Wielką Brytanię Związkowi Sowieckiemu po rozpoczęciu operacji „Barbarossa” została przyjęta przez Ankarę z mieszanymi uczuciami. Niepokoiła ich przede wszystkim perspektywa, że współpraca między Londynem a Moskwą będzie rozwijała się kosztem interesów Ankary. Brytyjczycy wiedzieli o tych obawach i po początkowej nieudanej próbie ich wykorzystania postanowili podjąć działania mające zapewnić Turków, że Londyn będzie respektował ich interesy. Brytyjczykom nie udało się osiągnąć tego celu. Co prawda namówił Moskwę do wydania deklaracji w sierpniu 1941 r. i do jej potwierdzenia w maju 1942 r., ale kroki te nie uspokoiły Ankary. Takie okoliczności jak niepoinformowanie strony tureckiej o zamiarze zawarcia porozumienia z Moskwą w lipcu czy okupacji Iranu w sierpniu 1941 r. oraz ukrywanie treści rozmów Edena ze Stalinem w Moskwie w grudniu 1941 r. dotyczących Turcji nadszarpnęły zaufanie Turków do Wielkiej Brytanii. Błędy te nie tylko popsuły wizerunek Londynu w oczach Ankary, ale utwierdzały również decydentów tureckich w przekonaniu, że Londyn może być zdolny do poświęcenia interesów Turcji.

\section{BIBLIOGRAFIA:}

Źródła (materiały archiwalne, źródła drukowane, memuarystyka):

The National Archives (Cabinet Papers 65/18/42) Kew, London.

The National Archives (Cabinet Papers 65/19/15) Kew, London.

The National Archives (Cabinet Papers 65/19/18) Kew, London.

The National Archives (Cabinet Papers 65/19/34) Kew, London.

The National Archives (Cabinet Papers 65/19/37) Kew, London.

The National Archives (Cabinet Papers 65/20/8) Kew, London.

The National Archives (Cabinet Papers 65/29/1) Kew, London.

The National Archives (Cabinet Papers 65/26/33) Kew, London.

The National Archives (Cabinet Papers 66/17/11) Kew, London.

The National Archives (Cabinet Papers 66/17/14) Kew, London.

The National Archives (Cabinet Papers 66/19/38) Kew, London.

The National Archives (Cabinet Papers 66/20/39) Kew, London.

The National Archives (Cabinet Papers 66/23/24) Kew, London. 
The National Archives (Cabinet Papers 66/26/34) Kew, London. The National Archives (Cabinet Papers 66/29/10) Kew, London. The National Archives (Cabinet Papers 79/21/29) Kew, London. The National Archives (Cabinet Papers 80/36) Kew, London. The National Archives (Foreign Office 371/30029/R 8224/10/44) Kew, London. The National Archives (Foreign Office 371/30029/ R 8550/10/44) Kew, London. The National Archives (Foreign Office 371/30029/R 8583/10/44) Kew, London. The National Archives (Foreign Office 371/30040/R 6759/19/44) Kew, London. The National Archives (Foreign Office 371/30068/R 7097/112/44) Kew, London. The National Archives (Foreign Office 371/30068/R 7312/122/44) Kew, London. The National Archives (Foreign Office 371/30068/R 7582/112/44) Kew, London. The National Archives (Foreign Office 371/30076/R 8358/139/44) Kew, London. The National Archives (Foreign Office 371/30083/R 7912/179/44) Kew, London. The National Archives (Foreign Office 371/30083/R 8537/179/44) Kew, London. The National Archives (Foreign Office 371/30084/R 8839/179/44) Kew, London. The National Archives (Foreign Office 371/30086/R 10031/179/44) Kew, London. The National Archives (Foreign Office 371/30086/R 10140/179/44) Kew, London. The National Archives (Foreign Office 371/30086/R 10558/179/44) Kew, London. The National Archives (Foreign Office 371/30091/R 6352/236/44) Kew, London. The National Archives (Foreign Office 371/30092/R 6581/236/44) Kew, London. The National Archives (Foreign Office 371/30092/R 6658/236/44) Kew, London. The National Archives (Foreign Office 371/30093/R 5036/236/44) Kew, London. The National Archives (Foreign Office 371/30093/R 7875/236/44) Kew, London. The National Archives (Foreign Office 371/30093/R 7908/236/44) Kew, London. The National Archives (Foreign Office 371/30094/R 10509/236/44) Kew, London. The National Archives (Foreign Office 371/30094/R 10883/236/44) Kew, London. The National Archives (Foreign Office 371/30126/R 6363/1934/44) Kew, London. The National Archives (Foreign Office 371/33330/R 2379/50/44) Kew, London. The National Archives (Foreign Office 371/33332/R 6507/50/44) Kew, London. The National Archives (Foreign Office 371/33338/R 706/70/44) Kew, London. The National Archives (Foreign Office 371/33339/R 3225/70/44) Kew, London. The National Archives (Foreign Office 371/33339/R 3742/70/44) Kew, London. The National Archives (Foreign Office 371/33340/R 316/72/44) Kew, London. The National Archives (Foreign Office 371/33340/R 451/72/44) Kew, London. The National Archives (Foreign Office 371/33340/R 2073/72/44) Kew, London. The National Archives (Foreign Office 371/33341/R 3494/72/44) Kew, London. The National Archives (Foreign Office 371/33349/R 6049/134/44) Kew, London. The National Archives (Foreign Office 371/33349/R 6309/134/44) Kew, London. The National Archives (Foreign Office 371/33350/R 6337/134/44) Kew, London. The National Archives (Foreign Office 371/33353/R 8548/134/44) Kew, London. The National Archives (Foreign Office 371/33353/R 8553/134/44) Kew, London. The National Archives (Foreign Office 371/33362/R 2343/403/44) Kew, London. The National Archives (Foreign Office 371/33385/R 6547/1429/44) Kew, London. 
The National Archives (Foreign Office 424/286) Kew, London.

The National Archives (Prime Minister's Office files 3/445/8), Kew, London.

The National Archives (War Office 106/3195), Kew, London.

The National Archives (War Office 216/25), Kew, London.

Gilbert, M. (red.). (2000) The Churchill War Papers. London, New York: W.W. Norton \& Company.

Perkins, E.R. (1959, 1963). Foreign Relations of the United States, Diplomatic Papers (1941: tom 4, 1942: tom 4). Washington: United States Government Printing Office.

Dilks, D. (red.). (1971). The Diaries of Sir Alexander Cadogan, 1938-1945. London: Cassell.

Knatchbull-Hugessen, H. (1949). Diplomate in Peace and War. London: Murray.

\section{Opracowania (monografie i artykuły naukowe):}

Dębski, S. (2007). Między Berlinem a Moskwą. Stosunki niemiecko-sowieckie 1939-1941. Warszawa: Polski Instytut Spraw Międzynarodowych.

Deringil, S. (2004). Turkish Foreign Policy during the Second World War: an Active Neutrality. Cambridge, New York, New Rochelle, Melbourne, Sydney: Cambridge University Press.

Glasneck, J., Kircheisen, I. (1968). Türkei und Afghanistan - Brennpunkte der Orientpolitik im Zweiten Weltkrieg. Berlin: VEB - Deutscher Verlag der Wissenschaften.

Hassel, A., MacRae, S. (2008). Przymierze wrogów. Warszawa: Świat Książki.

Inanç, G. (2006). The Politics of 'Active Neutrality' on the Eve of a New Order: The Case of Turkish Chrome Sales during the Second Word War. Middle Eastern Studies, 6, 907-915.

Krecker, L. (1964). Deutschland und die Türkei im zweiten Weltkrieg. Frankfurt am Main: Vittorio Klostermann.

Robertson J. (1986). Turkey and Allied Strategy 1941-1945. London, New York: Garand Publishing.

Tamkin, N. (2009). Britain, Turkey and the Soviet Union, 1940-45. Strategy, Diplomacy and Intelligence in the Eastern Mediterranean. London: Palgrave Macmillan.

Woodward, L. (1975). British Foreign Policy in the Second World War. London: Her Majesty Stationery Office.

Zdulski, K. (2009). III Rzesza a świat islamu. Łódź: Ibidem.

Zdulski, K. (2015). Wielka Brytania wobec niewypełnienia przez Turcję zobowiązań wynikających z układu o wzajemnej pomocy z 19 października 1939 r. W: R. Bania, R. Czulda., K. Zdulski, (red.), Wyzwania i problemy współczesnych stosunków międzynarodowych. Bezpieczeństwo, dyplomacja, gospodarka, historia i polityka (s. 327-341). Łódź: Polskie Towarzystwo Studiów Międzynarodowych.

Zdulski K. (2016). Turcja w brytyjskich planach obronyBliskiego Wschodu podczas „dziwnej wojny”. Przeglad Historyczno-Wojskowy, 1, 57-84. 